\title{
Relationship between sounds and disc displacement of the temporomandibular joint using magnetic resonance imaging
}

\author{
Relação entre ruído e deslocamento de disco da articulação \\ temporomandibular utilizando imagem de ressonância magnética
}

\begin{abstract}
Purpose: Magnetic resonance imaging (MRI) is useful for interpreting temporomandibular joint (TMJ) disorders including disc displacement. This study aimed to evaluate the relationship between TMJ sounds and disc displacement with and without reduction by clinical examination and MRI.

Methods: A sample of 58 patients was clinically examined when after being referred to MRI due to signs and symptoms of unilateral or bilateral TMJ disc displacement. The diagnosis obtained using MRI was compared with the clinical findings for the presence or absence of articular sounds.

Results: Most patients ( $n=39 ; 67 \%$ ) had joint sounds manifested as clicking; the other 19 patients (33\%) did not present sounds. Among the 39 patients with sounds, bilateral clicking was observed in $29(74 \%)$, and unilateral clicking in $10(26 \%)$ patients. Unilateral clicking was equally observed on the right and left sides, each occurring in 5 five patients (13\%).

Conclusion: The results suggest that articular sounds do not occur exclusively in TMJ with disc displacement with reduction. The presence or absence of joint sounds will not suffice as the only aspect criterion to be considered in the differential diagnosis of disc displacement with and without reduction.
\end{abstract}

Key words: Temporomandibular joint; disc displacement; joint sounds; magnetic resonance imaging

\section{Resumo}

Objetivo: A ressonância magnética nuclear (RMN) é de grande utilidade para o diagnóstico das desordens temporomandibulares, inclusive o deslocamento de disco é muito comum. $\bigcirc$ objetivo deste estudo foi avaliar a relação entre ruído articular e deslocamento de disco com e sem redução por meio de avaliação clinica e ressonância magnética nuclear.

Metodologia: $O$ estudo examinou 58 pacientes clinicamente, que foram submetidos à RMN quando apresentavam de sinais e sintomas de deslocamento de disco uni ou bilateral. $\mathrm{O}$ diagnóstico obtido pela RMN foi comparado com os achados clínicos relativos à presença ou não de ruído articular.

Resultados: Dos 58 indivíduos estudados, 39 (67\%) apresentaram ruído articular do tipo click, os restantes 19 (33\%) não apresentaram ruídos. Dos 39 com ruído, a ocorrência bilateral foi de $29(74 \%)$ e unilateral em $10(26 \%)$ casos, sendo 5 (13\%) do lado direito e 5 (13\%) do lado esquerdo.

Conclusão: Os resultados demonstraram que os ruídos articulares não estão restritos a articulações com deslocamento de disco com redução. A presença ou ausência de ruído articular não devem ser os únicos aspectos considerados para o diagnóstico diferencial entre deslocamento de disco com e sem redução.

Palavras-chave: Articulação temporomandibular; deslocamento de disco; ruído articular; imagem por ressonância magnética

\author{
Maurício André Bisi a,b \\ Karen Dantur Batista Chaves \\ Edela Puricellia \\ Deise Ponzoni a \\ Eleutério Araújo Martins b
}

- Federal University of Rio Grande do Sul, Porto Alegre, RS, Brazil

${ }^{\mathrm{b}} \mathrm{ABO}-\mathrm{RS}$, Porto Alegre, RS, Brazil

\author{
Correspondence: \\ Mauricio André Bisi \\ R. Conde D'Eu, 1405 B \\ Caxias do Sul, RS - Brasil \\ 95076-090 \\ E-mail: maubisi@hotmail.com
}




\section{Introduction}

The normal temporomandibular joint (TMJ) is described as silent. However, sounds may be heard in individuals who may or may not present the typical symptoms of temporomandibular disorders (TMD) (1). Different mechanisms are involved in the occurrence of TMJ sounds, which probably reflect some abnormality in the structure and function of the joint, such as the impact between joint structures, the deformation of these structures, and the changes in the quality of the synovial fluid. The impacts between the condyle and the mandibular fossa are associated with subluxation (Fig. 1), disc displacement (Fig. 2) and osteoarthritic changes (Fig. 3). These events lead to an increase in the friction between joint elements and thus generate sounds (1).
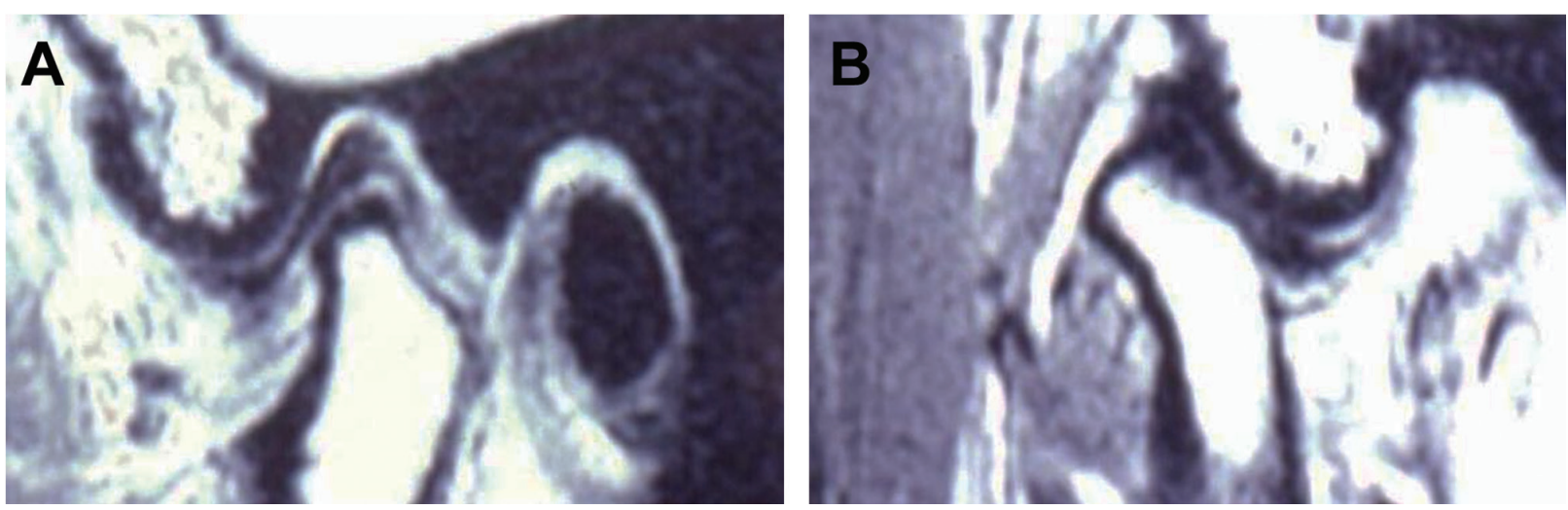

Fig. 1. Subluxation: (A) mouth closed; (B) mouth opened.
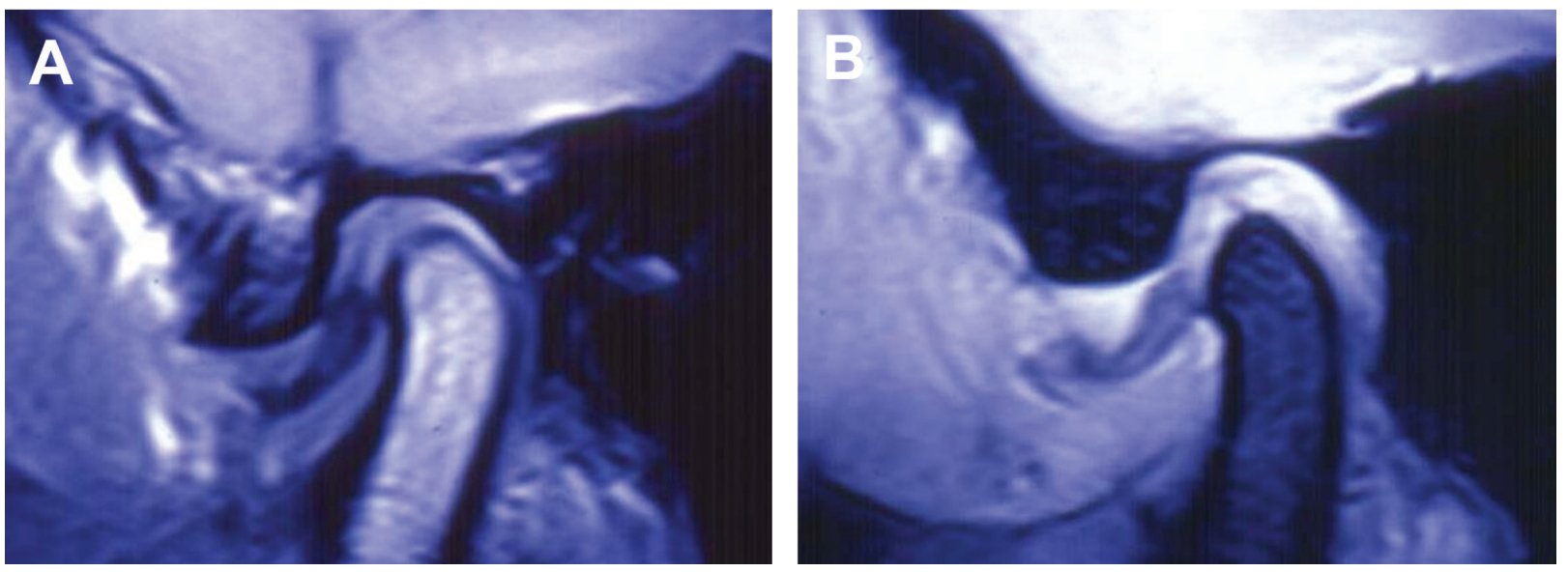

Fig. 2. Disc displacement: (A) mouth closed; (B) mouth opened.

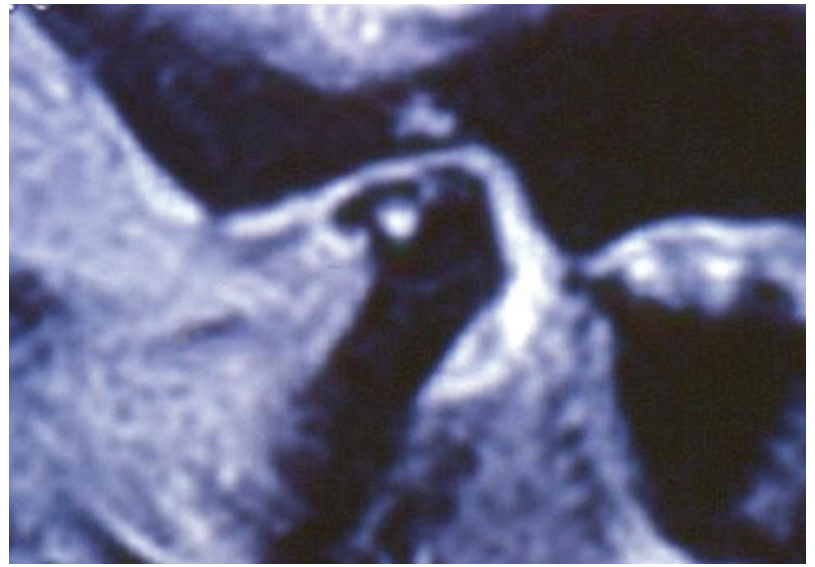

Fig. 3. Condyle with ostheorarthritic change. 
Although the presence of TMJ abnormalities does not necessarily imply the progression of symptoms, a detailed investigation is required every time any of the typical TMD symptoms is diagnosed. The efficient evaluation of temporomandibular sounds may play an important role in TMD diagnosis and treatment (2).

One of the criteria adopted to differentiate disc displacements with reduction and those without reduction is the presence of articular sound. In previous papers, disc displacement without reduction was associated with articular sounds $(3,4)$. Nevertheless, Miller et al. (5) reported that approximately $15 \%$ of TMJs with preliminary diagnoses of disc displacement with reduction, based on the presence of a reciprocal click, exhibited disc displacement without reduction in magnetic resonance imaging (MRI). Conversely, Mueller-Leisse et al. (6) concluded that articular sounds are not helpful as indicators of the degree of internal TMJ dysfunction. These authors reported that audible sounds during mouth opening or closing or lateral jaw movements were observed in $52 \%$ of TMJs diagnosed with disc displacement without reduction, in $67.5 \%$ of TMJs with reduction, and in $68.7 \%$ of joints whose disc was properly positioned. In another study (7), clicking was observed in $36 \%$ of the joints presenting normal disc positions, in $82 \%$ of joints with disc displacement with reduction, and in $55 \%$ of TMJs exhibiting disc displacement without reduction. These studies used MRI as a diagnosis tool.

Other studies have demonstrated the usefulness of MRI in the diagnosis of TMD (8-10). MRI affords excellent descriptions of the TMJ anatomy of and the likely disorders that affect the structure due to the high gain using contrasts and to the high definition. Serial images of opened and closed mouths permit the morphological and functional evaluation of the TMJs. These images also allow the assessment of the degree of abnormality when such condition is present (11).

This study evaluated the relationship between articular sound and disc displacement with and without reduction using clinical examination and magnetic resonance imaging.

\section{Methods}

This study was approved by the Ethics Committee of the School of Dentistry, Federal University of Rio Grande do Sul, Brazil.

A retrospective study was conducted with 58 individuals referred for an evaluation of temporomandibular conditions to the Service of the Course of Occlusion Studies, School of
Dentistry, Federal University of Rio Grande do Sul, Porto Alegre, Brazil. The patients underwent clinical examination by two calibrated examiners and then by bilateral MRI. The images were obtained on the parasagittal plane and on the coronal plane in the closed-mouth position. Images were also obtained in the parasagittal plane, open-mouth position. Patients underwent MRI when signs and symptoms of unilateral or bilateral disc displacement were observed. The final diagnosis of the disc position was based on the MRI findings, according to criteria described by Westesson et al. (12). The diagnosis obtained by MRI was compared to the clinical findings related to the presence or absence of articular sound using the $\chi^{2}$ test.

\section{Results}

From the total of 58 subjects examined, 39 presented articular sounds defined as clicking. The remaining 19 subjects did not present any articular sounds (Table 1).

When these variables are analyzed conjointly, 24 patients who presented disc displacement with reduction also exhibited intra-articular sound (click). Whenever disc displacement with reduction was observed, the disorder occurred bilaterally. Nevertheless, 15 patients who had disc displacement without reduction presented unilateral or bilateral sound, while the other 10 patients with disc displacement without reduction did not produce any articular sound. Nine patients had no changes in disc position and noise.

\section{Discussion}

Different methods have been used to obtain TMJ images (13). The physical proximity of the TMJ to the cranial base makes it more difficult to obtain clear radiographs, without superimposition of structures. Technological advancements allowed section images of hard tissues and accurate descriptions of soft tissues to be obtained, which in the past were feasible only by conducting invasive procedures (14). MRI of the TMJ provides essential information on the position, signal intensity, morphology and structure of the articular disc. The technique also offers insights into the cortical and medullar bone tissue and the retrodisc tissue (15). MRI is a non-invasive method useful in the detection of TMJ disc displacements and in the landmarking of disc position in patients suspected of internal disorders. Clinical and experimental studies have demonstrated the high accuracy afforded by this imaging technique (10).
Table 1. Clinical findings related to disc displacement and the presence or absence of temporomandibular

joint sounds.

\begin{tabular}{|c|c|c|c|c|c|}
\hline \multirow{2}{*}{ Displacement/ Sounds } & \multicolumn{3}{|c|}{ Present } & \multirow{2}{*}{ Absent } & \multirow{2}{*}{$\mathrm{N}$} \\
\hline & Right & Left & Bilateral & & \\
\hline With reduction & - & - & $24(41.4 \%)$ & - & $24(41.4 \%)$ \\
\hline Without reduction & $5(8.6 \%)$ & $5(8.6 \%)$ & $5(8.6 \%)$ & $10(17.2 \%)$ & $25(43.0 \%)$ \\
\hline Normal & \multicolumn{3}{|c|}{ - } & $9(15.6 \%)$ & 9 (15.5\%) \\
\hline TOTAL & \multicolumn{3}{|c|}{$39(67.2 \%)^{*}$} & $19(32.8 \%)^{*}$ & $58(100 \%)$ \\
\hline
\end{tabular}

${ }^{*} \chi^{2}=38.544, P<0.001$. 
Disc displacements are defined as abnormal positions of the articular disc against the condyle and the TMJ articular eminence. The disorder has been linked to pain, articular sounds and limited mouth opening (16). Articular sounds of the clicking type as during mouth opening and closing are characteristic clinical signs of disc displacement with reduction (17). Nevertheless, the present results demonstrate that articular sounds are not restricted to the TMJs that have that disorder. The findings of the present study indicate a positive correlation between clicking and disc displacement with reduction. However, this sound also occurred in disc displacement without reduction. This corroborates with other studies, casting doubt over the use of clinical examination as the only diagnostic approach to be adopted for the detection of internal TMJ disorders (5).

Other clinical examination procedures may be used to diagnose disc displacement, such as mouth opening movements in mandibular protrusion and the use of tongue depressors between the palatal arches. In this case, the elimination of articular sound may indicate disc displacement without reduction (18). In the present study, the TMJs with disc displacement without reduction also presented sounds, similarly to the findings by Miller et al. (5). However, the sounds occurred on both the affected and unaffected sides, which demonstrates the functional relationship between the right and the left TMJ sides.

The reporting of different sounds concurrently may influence results because sounds can vary with the change in disc position due to the treatments conducted - and even in the absence of any intervention. This situation has been described by Lundh et al. (19) with 23 disc displacement patients who presented reciprocal clicking and had no treatment for 52 weeks. The authors observed that the reciprocal sound disappeared in two patients after six weeks, and in only one patient, mandible locking developed after two weeks. However, the reciprocal sound remained unaltered in the other patients.

Some cases of disc displacement without reduction were observed with the occurrence of articular sound. It is believed that tissue changes in the retrodisc portion, which is subject to articular efforts, explain this clinical sign. Miller et al. (5) described the mechanism involved in sounds observed in TMJs presenting disc displacement without reduction as a friction impact between the condyle and the posterior band of the displaced disc. This kind of impact would cause a single sound at the maximum amplitude of movement.

The extension of disc displacement also influences the occurrence of sounds in TMJs with disc displacement without reduction. Kurita et al. (20) concluded that permanently displaced articular discs are more anteriorly positioned compared to those presenting reduction. The position of the articular disc during the mouth opening movement may determine the type of disc displacement and the occurrence of sounds. Articular sounds occur more often in cases of disc displacement with reduction, though sound may also be observed in disc displacement without reduction. This suggests that the more anteriorly located the disc inside the TMJ, the lower the chances that it should produce sounds. The present study demonstrated a variety of TMD signs and symptoms. Therefore, it is necessary to conduct accurate clinical diagnosis of the anatomic and functional changes that are manifested in the TMJ. In this scenario, high quality images may be used concurrently to reach a correct diagnosis, which in turn helps to define the best treatment approach for specific cases.

\section{Conclusions}

The presence or absence of articular sound should not be the only factor considered in the differential diagnosis of disc displacement with and without reduction. Complementary exams, such as MRI, are highly valuable in the characterization of intra-articular disorders and thus improve accuracy in diagnosis and adequacy in treatment. A more detailed analysis on the occurrence of disc displacement may add to a better comprehension of these differences and thus establish more precise clinical criteria for the diagnosis of TMJ disorders.

\section{References}

1. Prinz JF. Physical mechanisms involved in the genesis of temporomandibular joint sounds. J Oral Rehabil 1998;25: 706-14.

2. Honda K, Natsumi Y, Urade M. Correlation between MRI evidence of degenerative condylar surface changes, induction of articular disc displacement and pathological joint sounds in the temporomandibular joint. Gerodontology 2008;25:251-7.

3. Gray RJM, Davies SJ, Quayle AA. Temporomandibular disorders: a clinical approach. London: British Dental Journal, 1995

4. Limchaichana N, Nilsson H, Ekberg EC, Nilner M, Petersson A. Clinical diagnoses and MRI findings in patients with TMD pain. Oral Rehabil 2007;34:237-45.

5. Miller TL, Katzberg RW, Tallents RH, Bessette RW, Hayakawa K. Temporomandibular joint clicking with nonreducing anterior displacement of the meniscus. Radiology 1985;154:121-4.
6. Müller-Leisse C, Augthun M, Baver W, Roth A, Günther R. Anterior disc displacement without reduction in the temporomandibular joint: MRI and associated clinical findings. J Magn Reson Imaging 1996;6:769-74.

7. Barclay P, Hollender LG, Maravilla KR, Truelove EL. Comparison of clinical and magnetic resonance imaging diagnoses in patients with disk displacement in the temporomandibular joint. Oral Surg Oral Med Oral Pathol Oral Radiol Endod 1999;88:37-43.

8. Benbelaid R, Fleiter B. Sensitivity and specificity of a new MRI method evaluating temporo-mandibular join disc-condyle relationships : an in vivo study. Surg Radiol Anat 2006;28:71-5.

9. Brooks SL, Westesson PL. Temporomandibular joint: value of coronal MR images. Radiology 1993;188:317-21.

10. Tasaki MM, Westesson PL, Raubertas RF. Observer variation in interpretation of magnetic resonance images of the temporo- 
mandibular joint. Oral Surg Oral Med Oral Pathol 1993;76: 231-4.

11. Held P, Moritz M, Fellner C, Behr M, Gmeinwieser J. Magnetic resonance of the disk of the temporomandibular joint: MR imaging protocol. Clin Imaging 1996;20:204-1 1

12. Westesson PL, Katzberg RW, Tallents RH, Sanchez-Woodworth RE, Svensson SA, Espeland MA. Temporomandibular joint: comparison of MR images with cryosectional anatomy. Radiology 1987; 164:59-64.

13. Omnell KA. Historical review of temporomandibular joint arthrography. In: Moffet BC, Westesson PL editors. Diagnosis of internal derangements of the temporomandibular joint. Seattle: University of Washington Continuing Dental Education; 1984. p. 1-3.

14. Major PW, Kinniburgh RD, Nebbe B, Prasad NG, Glover KE. Tomographic assessment of temporomandibular joint osseous articular surface contour and spatial relationships associated with disc displacement and disc length. Am J Orthod Dentofacial Orthop 2002; 121:152-61.
15. Sener S, Akgünlü F. Correlation of different MRI characteristics of anterior disc displacement with reduction and without reduction. J Contemp Dent Pract 2005;6:26-36.

16. Emshoff R, Innerhofer K, Rudisch A, Bertram S. Clinical versus magnetic resonance imaging findings with internal derangement of the temporomandibular joint: an evaluation of anterior disc displacement without reduction. J Oral Maxillofac Surg 2002;60:36-41.

17. Okeson JP. Dores bucofaciais de bell. 6.ed. São Paulo: Quintessence; 2006.

18. Isberg A. Disfunção da articulação temporomandibular: um guia para o clinico. São Paulo: Artes Médicas Editora; 2005.

19. Lundh H, Westesson PL, Kopp S. Anterior repositioning splint in the treatment of temporomandibular joints with reciprocal clicking: comparison with a flat occlusal splint and an untreated control group. Oral Surg Oral Med Oral Pathol 1985;60:131-6.

20. Kurita $H$, Ohtsuka A, Kobayashi $H$, Kurashina K. The relationship between the degree of disk displacement and ability to perform disk reduction. Oral Surg Oral Med Oral Pathol Oral Radiol Endod 2000;90: 16-20. 